\title{
Determinants of Zakat Behavior
}

\author{
Diah Isnaini Asiati \& Reza Nopriyansah \\ Muhammadiyah University of Palembang, Indonesia \\ Email: diah isnaini@yahoo.com
}

\begin{abstract}
Zakat is a popular Islamic weapon in shaping the welfare of society which has moral, social, and economic values. Economically, zakat balances social life by distributing wealth from rich people to poor societies. However, the greatness that is aimed to be realized was not sufficient in encouraging people to implement zakat itself, even for its value owners which is Moslem's community. This is why the target of obtaining zakat in each region as well as national does not always achieved. This research tries to find answers that explain why people are willing to pay zakat. The development of the idea is carried out by taking all the indicators that indicate the willingness of people to pay zakat. The number of indicators reaches 52 statements. The research was developed with a causal design based on primary data. A total of 100 people were determined by cluster sampling who were involved in filling out questionnaires related to zakat behavior. The respondents came from all sub-districts in Palembang City. The data obtained is then processed using analysis factor in order to determine the choice factors that can be used as the basis for zakat behavior. The selected factors are then processed using multiple linear regression. The results showed that there are 12 factors that can be identified as the basis for zakat behavior. Following this, the test results proved that all factors influence zakat behavior and there are partially various results. Among these factors are knowledge, belief, external motivation, work, and institutions; they have been shown to significantly influence zakat behavior. As for promotion, persuasion, internal motivation, WOM, income, distribution, and individual sales, the results proved that they have insignificant effect to the behavior of zakat people. Among these factors, personal income and sales showed a negative influence.
\end{abstract}

Keywords knowledge, trust, external motivation, employment, institutional promotion, persuasion, internal motivation, WOM, income, distribution, and personal selling

\section{Introduction}

Basically, the substance of all economic systems is to build social welfare, a condition where everyone acquires a chart of the various resources that have been provided by Allah SWT. This is an ideal condition as a form of the almighty's will to create man and facilitate all his life necessities. To achieve this condition, one of the mechanisms regulated in Islam is zakat.

Zakat has moral, social, and economic functions (Mannan, 1997). Economically, the purpose of zakat is to distribute wealth from the rich to the poor. The potential for zakat in Indonesia continues to grow:

Table 1. ZIS Collection Growth

\begin{tabular}{|l|l|l|l|}
\hline Year & ZIS (Rp billion) & Growth (\%) & GDP growth (\%) \\
\hline 2008 & 920.00 & 24.32 & 6.2 \\
\hline 2009 & $1,200.00$ & 30.43 & 4.9 \\
\hline 2010 & $1,500.00$ & 25.00 & 6.1 \\
\hline 2011 & $1,729.00$ & 15.27 & 6.5 \\
\hline 2012 & $2,212.00$ & 27.94 & 6.23 \\
\hline 2013 & $2,639.00$ & 19.30 & 5.78 \\
\hline 2014 & $3,300.00$ & 25.05 & 5.02 \\
\hline 2015 & $3,650.00$ & 10.61 & 5.04 \\
\hline
\end{tabular}




\begin{tabular}{|l|l|l|l|}
\hline 2016 & $5,017.29$ & 37.46 & 5.02 \\
\hline 2017 & $6,224.37$ & 24.06 & 5.07 \\
\hline 2018 & $8,117.0$ & 30.42 & 5.17 \\
\hline
\end{tabular}

Source: BAZNAS, 2020

Although the amount of zakat earned continues to increase every year, this amount is still far from the expected target. The acceptance of zakat in Indonesia as a country with the largest Moslem population is still minimum. In 2010, the potential for zakat in Indonesia reached 230 trillion, but only 8 trillion (3.5\%) were collected (Andini, 2020). As for South Sumatra, according to the head of BAZNAS South Sumatra, the realization of zakat collection as of July 2019 missed because it was only able to collect 1.7 billion from 2.25 billion with a target of 4.5 billion at the end of the year (Rosana, 2019). This gap between the target and the achievement certainly also hinders the achievement of rahmatan lil 'alamin.

Several factors have been studied for their influence on the behavior of zakat people. Since zakat is closely related to income, it makes sense that income is a major element of people's willingness to give zakat. However, Mirawati, Malik, and Ibrahim (2018), Huda \& Ghofur (2012), and Maulana (2020), prove that income has no significant effect on the willingness of muzakki (compulsory zakat) to pay zakat. This means when a person's income has reached the nishab (minimum calculation of income affected by zakat), that person feels that his/her income is still insufficient to meet various life needs, so that, it is too small to have an influence on the willingness to pay zakat. Moreover, Maulana (2020) provides more detailed findings that the relationship between income and the amount of zakat is inelastic. The percentage of an increase in the amount of zakat is smaller than the percentage of an increase in someone's income.

Many other factors have been studied as a cause of people's willingness to pay zakat. To name a few is religiosity, Yazid (2017), Mirawati, Tanjung, and Arif (2019), Maulana (2020), and Maulidina \& Solekah (2020), all of them prove that the effect of religiosity on people's willingness to pay zakat, although they used various indicators. The other factors that have generally been appointed as influencers, such as service quality, institutional image, beliefs, attitudes, etc., have also been widely demonstrated. Nevertheless, from the various empirical studies above, all of them show a low determinant coefficient, which ranges from $7.4 \%$ to $30 \%$. This shows that there are still many factors that need to be revealed as another consideration that encourages muzakki to give zakat.

\section{Literature Review}

Consumer behavior is a dynamic field of study. Kotler \& Keller (2016) demonstrates a model of consumer behavior that describes both internal and external factors of consumers. The intended external factors are as follow:

1. The marketing mix that comes from inside the company organization consists of the elements of product, price, place, and promotion. People, process, physical evidence, and productivity can be added to this element of service.

2. Non-company external elements which include all elements of the uncontrollable environment such as economy, technology, law, nature, culture, and competition.

Furthermore, the internal elements are:

1. All inherent elements with consumers include cultural, social, personal, and psychological.

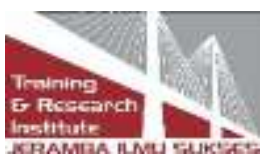


2. The stages in the purchasing decision process, in which certain situations, the consumers can alter their purchase decision.

Even though the overall meaning is the same, Engel et al. (2012) make the classification of the effect derived from:

1. Individual influence, which means that all elements come from the individual consumer itself.

2. Organizational influence, which means that all elements are deliberately designed and created by the company organization to encourage attractiveness, so that, consumers are willing to make purchases.

3. Acquisition, which means that all things related to the efforts and the ways of consumers to get the product that they are looking for, include the decision to buy, other products that are considered to be purchased, where to buy, how to pay, and how the product arrives at home.

4. Consumption, which means that all things related to the use of the product, include how to use the product, store it, who can use it, how much is used, and whether the product meets expectations.

5. Placement, which means that everything about the product after use, include how to stay, how can get it, how after use, how to sell it again, and how to reprocess the product.

A consumer may not respond to a product based on only one factor. The factors that influence this will differ between consumers and over time. This is the dynamics of consumer behavior, so that, some people judge their relative importance. Nonetheless, the long and repetitive experiences still provide clues to efforts in better consumers understanding.

\section{Research Methodology}

This research was conducted with a quantitative approach in Palembang City which consists of 18 districts. Samples were taken of 100 by cluster sampling. A number of 51 indicators were developed derived from various variables determined through group discussion. A total of 42 indicators were processed to determine their relative factors, while the remaining 9 indicators were only used to determine their effects. Primary data as the main research data were collected using a questionnaire. The data obtained were then analyzed using analysis factor followed by multiple linear regression.

\section{Findings and Discussions}

Based on the results of obtaining answers through a questionnaire, the results of a descriptive analysis showed that respondents came from 18 sub-districts in Palembang City with a nonproportional number for the head of the family/sub-district. Overall, respondents have worked and are willing to provide answers to the statements in the questionnaire.

Furthermore, the instrument test was carried out on the respondent's answer, in order to ensure that the data obtained was suitable as a basis for analysis. The results of the instrument test showed that all indicators proved valid because each indicator had a calculated $r$ value $>r$ table (0.361) with a number range of $0.372-0.911$. The reliability value is obtained by Cronbach's Alpha $=0.7989>$ reliability standard $=0.6$, so that, the instrument was also proved to be reliable. 


\subsection{Findings}

4.1.1.Analysis Factors (PCA)

a. Kaiser-Mayer-Olkin (KMO) and Bartlett Test

Table 2. KMO and Bartlett's Test

$\begin{array}{cll}\text { Kaiser-Meyer-Olkin Measure of Sampling Adequacy. } & .717 \\ \text { Bartlett's Test of Sphericity } & \text { Approx. Chi-Square } & 2473,326 \\ & \text { Df } & 861 \\ \text { Sig. } & .000\end{array}$

Source: SPSS Output Results, 2020

$\mathrm{KMO}$ and Bartlett's test output is useful for determining whether the indicator can be processed further. Based on the table above, $\mathrm{KMO}$ value $=0.717>0.5$ and value of Bartlett Test $=0.000<0.05$. Thus, these results qualify for further analysis.

\section{b. Anti Image Matrices}

Anti Image Matrices useful for knowing and determining which indicators are suitable for use in analysis factor. The requirement that must be required is that the MSA value is $>0.5$. The results of the calculation turned out that all indicators had MSA values $>0.5$ with a range of $0.545-0.863$.

\section{c. Communalities}

Communalities indicates whether the indicators used are able to show the factors or not. The indicator is considered capable if the extraction value is $>0.5$. The calculation results show that all indicators have extraction value $>0.5$ with a range of $0.567-0.828$.

\section{d. Factoring or Extraction Process}

In this process, Principal Components Analyze (PCA) is used with the following results;

Table 3. PCA Extraction Results

\begin{tabular}{cccc}
\hline \multirow{4}{*}{$\begin{array}{c}\text { Initial Eigenvalues } \\
\text { Component }\end{array}$} & Total & of Variance & Cumulative\% \\
\hline 1 & 9,954 & 23,701 & 23,701 \\
2 & 3,280 & 7,809 & 31,510 \\
3 & 3,054 & 7,273 & 38,782 \\
4 & 2,417 & 5,754 & 44,536 \\
5 & 1,998 & 4,757 & 49,293 \\
6 & 1,790 & 4,263 & 53,556 \\
7 & 1,740 & 4,143 & 57,699 \\
8 & 1,660 & 3,952 & 61,651 \\
9 & 1,330 & 3,168 & 64,818 \\
10 & 1,263 & 3,006 & 67,825
\end{tabular}




\begin{tabular}{|c|c|c|c|}
\hline 11 & 1,113 & 2,651 & 70,476 \\
\hline 12 & 1,067 & 2,541 & 73,175 \\
\hline 13 & .907 & 2,159 & 75,175 \\
\hline 14 & .878 & 2,091 & 77,267 \\
\hline 15 & .830 & 1,976 & 79,243 \\
\hline 16 & .784 & 1,866 & 81,109 \\
\hline 17 & .722 & 1,718 & 82,828 \\
\hline 18 & .709 & 1,688 & 84,516 \\
\hline 19 & .637 & 1,516 & 86,032 \\
\hline 20 & .561 & 1,335 & 87,367 \\
\hline 21 & .524 & 1,247 & 88,614 \\
\hline 22 & .481 & 1,145 & 89,759 \\
\hline 23 & .444 & 1,056 & 90,815 \\
\hline 24 & .400 & .952 & 91,767 \\
\hline 25 & .373 & .887 & 92,655 \\
\hline 26 & .365 & .870 & 93,524 \\
\hline 27 & .337 & .803 & 94,328 \\
\hline 28 & .284 & .677 & 95,004 \\
\hline 29 & .257 & .612 & 95,616 \\
\hline 30 & .240 & .572 & 96,188 \\
\hline 31 & .218 & .520 & 96,708 \\
\hline 32 & .206 & .491 & 97,198 \\
\hline 33 & .195 & .465 & 97,664 \\
\hline 34 & .185 & .441 & 98,105 \\
\hline 35 & .153 & .365 & 98,470 \\
\hline 36 & .132 & .314 & 98,783 \\
\hline 37 & .113 & .269 & 99,053 \\
\hline 38 & .107 & .255 & 99,308 \\
\hline 39 & .088 & .210 & 99,518 \\
\hline 40 & .084 & .199 & 99,718 \\
\hline 41 & .067 & .159 & 99,876 \\
\hline 42 & .052 & .124 & 100,000 \\
\hline
\end{tabular}

Source: SPSS Output Results, 2020

The table above is the extraction result of the variables that influence the decision to pay zakat. The total number of correlated factors is 42 variables. Next, we will see the factors of the extraction results as follows:

Table 4. Total PCA Result Factors

\begin{tabular}{ccc}
\hline $\begin{array}{c}\text { Extraction Sums of Squared Loadings } \\
\text { \%otal }\end{array}$ & of Variance & Cumulative\% \\
\hline 9,954 & 23,701 & 23,701 \\
3,280 & 7,809 & 31,510 \\
3,054 & 7,273 & 38,782 \\
2,417 & 5,754 & 44,536 \\
1,998 & 4,757 & 49,293 \\
1,790 & 4,263 & 53,556 \\
1,740 & 4,143 & 57,699 \\
1,660 & 3,952 & 61,651 \\
1,330 & 3,168 & 64,818 \\
1,263 & 3,006 & 67,825 \\
1,113 & 2,651 & 70,476
\end{tabular}




\begin{tabular}{rr}
2,541 & 73,017 \\
\hline
\end{tabular}

Source: SPSS Output Results, 2020

The table above shows that of the 42 variables previously extracted, 12 new factors were formed the respective ones, each has value of Eigen $>1$, for example a total factor of $1=$ $9.954>1$.

\section{e. Rotated Component Matrix}

Rotated component matrix is used to determine which indicators form a particular factor. The results are shown as follows;

Table 5. New Factors Are Formed

\begin{tabular}{|c|c|}
\hline Factor & Indicators which form the new factors \\
\hline \multirow{11}{*}{$\begin{array}{l}\text { Knowledge } \\
\text { Factor }\end{array}$} & 1. The steps to pay zakat maal are easy to understand (X9) \\
\hline & 2. The terms of paying zakat maal do not confuse me (X10) \\
\hline & 3. Zakat maal can be paid with an easy time calculation (X12) \\
\hline & 4. The procedure for paying zakat maal can be done easily (X13) \\
\hline & $\begin{array}{l}\text { 5. The amil zakat body helps me in the process of paying zakat } \\
\text { (X14) }\end{array}$ \\
\hline & 6. I know the meaning of zakat maal (X25) \\
\hline & $\begin{array}{l}\text { 7. I already know the amount of zakat maal that I have to pay on the } \\
\text { amount of my assets and income (X26) }\end{array}$ \\
\hline & 8. I know how to pay zakat maal (X27) \\
\hline & 9. I already know which agencies I can pay zakat on (X28) \\
\hline & 10. I know the benefits of paying zakat maal (X29) \\
\hline & 11. I know the impact of paying zakat maal (X30) \\
\hline \multirow{5}{*}{$\begin{array}{l}\text { Promotion } \\
\text { Factor }\end{array}$} & $\begin{array}{l}\text { 1. I know zakat maal from advertisements made by amil zakat } \\
\text { bodies in electronic media (X1) }\end{array}$ \\
\hline & $\begin{array}{l}\text { 2. I know zakat maal from advertisements made by the amil zakat } \\
\text { agency in print media (X2) }\end{array}$ \\
\hline & 3. I know zakat maal from friends and colleagues (X5) \\
\hline & 4. I know zakat maal from family (X6) \\
\hline & $\begin{array}{l}\text { 5. I've been contacted by an amil zakat officer to pay zakat maal } \\
\text { (X7) }\end{array}$ \\
\hline \multirow{3}{*}{$\begin{array}{l}\text { Persuasion } \\
\text { Factor }\end{array}$} & $\begin{array}{l}\text { 1. Amil zakat institutions always influence me to pay zakat maal } \\
\text { (X33) }\end{array}$ \\
\hline & $\begin{array}{l}\text { 2. The amil zakat institution was able to influence me to pay zakat } \\
\text { (X34) }\end{array}$ \\
\hline & $\begin{array}{l}\text { 3. I feel confident and reduce supervision of the amil zakat body } \\
\text { (X37) }\end{array}$ \\
\hline & 1. I defend the amil zakat agency from negative accusations (X40) \\
\hline Trust Factor & $\begin{array}{l}\text { 2. I give positive information to others about the amil zakat body } \\
\text { (X41) }\end{array}$ \\
\hline \multirow{4}{*}{$\begin{array}{l}\text { Internal } \\
\text { Motivation } \\
\text { Factors }\end{array}$} & $\begin{array}{l}\text { 1. The basic salary or wages that I received make it possible to pay } \\
\text { zakat maal (X16) }\end{array}$ \\
\hline & $\begin{array}{l}\text { 2. Paying zakat maal has become the intention because of being able } \\
\text { to do (X21) }\end{array}$ \\
\hline & 3. Paying zakat maal because it is the duty of a Moslem (X23) \\
\hline & 4. I ignore the negative information circulating about the amil zakat \\
\hline
\end{tabular}


body (X39)

1. The amil zakat body has an operational schedule every working day (X11)

Institutional

2. Amil zakat institutions always maintain relationships (31)

Factors

3. Amil zakat institutions always try to provide satisfaction in terms of service (X32)

4. Amil zakat institution is opened in communicating about the distribution of zakat maal that I pay (X35)

1. I am interested in participating events that is held by zakat maal distribution agencies (X4)

External

Motivation

2. I have other sources of income apart from income from salary, wages, and allowances (X19)

Factors

3. I find it easy to pay zakat because of having income from other sources (X20)

1. I have a salary or wages as a source of income (X15)

Income Factor

2. I have allowance that I received from my job (X17)

3. The allowance I received allows me to pay zakat maal (X18)

WOM factor

1. I suggest friends, family, or other people to pay zakat mal to one of the zakat management bodies (X42)

Distribution

1. I know where the zakat that I pay is distributed (X36)

Factors

2. I am not suspicious of the amil zakat body (X38)

1. I know the charity event organized by the amil zakat agency (X3)

2. Paying zakat maal because of feeling that zakat maal is a

Job Factor necessity (X22)

3. I pay zakat maal because it is obliged by the agency where I work (X24)

Personal

Selling Factor

1. I prefer to pay zakat mal through amil zakat officers who offer zakat distribution services (X8)

Source: SPSS output, 2020

\subsubsection{Multiple Linear Regression Analysis}

Based on all the indicators used, the analysis factor produces 12 factors that are considered to influence the decision for paying zakat. Furthermore, multiple linear regression analysis is used to see the effect of each factors. The results of the regression analysis are as follow;

Table 6. Coefficients

\begin{tabular}{|c|c|c|c|}
\hline \multirow[b]{2}{*}{ Model } & \multicolumn{2}{|c|}{$\begin{array}{l}\text { Unstandardized } \\
\text { Coefficients }\end{array}$} & \multirow{2}{*}{$\begin{array}{l}\text { Standardi } \\
\text { zed } \\
\text { Coefficie } \\
\text { nts } \\
\text { Beta }\end{array}$} \\
\hline & $\mathrm{B}$ & $\begin{array}{l}\text { Std. } \\
\text { Error }\end{array}$ & \\
\hline $1 \quad$ (Constant) & 37,750 & .306 & \\
\hline Knowledge Factor & 1,812 & .307 & .471 \\
\hline Promotion Factor & .387 & .307 & .100 \\
\hline Persuasion Factor & .198 & .307 & .051 \\
\hline Trust Factor & .695 & .307 & .180 \\
\hline
\end{tabular}




\begin{tabular}{ll|l|l|}
\hline Internal Motivation Factors & .452 & .307 & .117 \\
\hline Institutional Factors & 1,125 & .307 & .292 \\
\hline External Motivation Factors & .642 & .307 & .167 \\
\hline Income Factor & -.041 & .307 & -.011 \\
\hline WOM factor & .409 & .307 & .106 \\
\hline Distribution Factors & .139 & .307 & .036 \\
\hline Job Factor & .674 & .307 & .175 \\
\hline Personal Selling Factor & -375 & .307 & -.097 \\
\hline
\end{tabular}

Source: SPSS Output Results, 2020

As shown in Table 5, all factors have an influence value on the decision to pay zakat with varying coefficient values. There are ten factors that have a positive influence and two factors that have a negative influence. The coefficient value that appears is then tested as follows:

Table 6. ANOVA

\begin{tabular}{|c|c|c|c|c|c|c|}
\hline \multicolumn{2}{|c|}{ Model } & \multirow{2}{*}{$\begin{array}{l}\begin{array}{l}\text { Sum of } \\
\text { Squares }\end{array} \\
655,360\end{array}$} & \multirow{2}{*}{$\frac{\mathrm{df}}{12}$} & \multirow{2}{*}{$\begin{array}{l}\text { Mean } \\
\text { Square }\end{array}$} & \multirow{2}{*}{$\frac{F}{5,841}$} & \multirow{2}{*}{$\begin{array}{l}\text { Sig. } \\
.000 \mathrm{~b}\end{array}$} \\
\hline 1 & Regression & & & & & \\
\hline & Residual & 813,390 & 87 & 9,349 & & \\
\hline & Total & 1468,750 & 99 & & & \\
\hline
\end{tabular}

Source: SPSS Output Results, 2020

The F test results show the value of Sig F $0.000<\alpha=0.05$, which means that there is a significant effect of knowledge factors, promotion factors, persuasion factors, trust factors, internal motivation factors, institutional factors, external motivation factors, income factors, WOM, distribution factors, occupational factors, personal selling factors that also have a significant effect simultaneously on the decision to pay zakat.

Table 7. Coefficients

\begin{tabular}{llcl}
\multicolumn{1}{c}{ Model } & thitung & Sig. \\
\hline 1 & 123,460 & .000 \\
Knowledge Factor & 5,897 & .000 \\
Promotion Factor & 1,258 & .212 \\
Persuasion Factor & .643 & .522 \\
Trust Factor & 2,262 & .026 \\
Internal Motivation Factors & 1,470 & .145 \\
Institutional Factors & 3,660 & .000 \\
External Motivation Factors & 2,088 & .040 \\
Income Factor & -134 & .894 \\
WOM factor & 1,330 & .187 \\
Distribution Factors & .451 & .653 \\
Job Factor & 2,195 & .031
\end{tabular}




\begin{tabular}{crr} 
Personal Selling Factor & $-1,219 \quad .226$ \\
\hline
\end{tabular}

Source: SPSS Output Results, 2020

The partial test results prove that the factors of knowledge, trust, institutional, external motivation, and work, have a significant effect on the decision to pay zakat while the factors of promotion, persuasion, internal motivation, income, WOM, distribution and personal selling have no significant effect on the decision to pay zakat. The coefficient of determination is equal to $37 \%$ while the remaining $63 \%$ is explained by other variables outside the study.

\subsection{Discussion}

The results of hypothesis testing in this study are not too different comparing to some of the previous studies. The coefficient of determination has not moved in a quite higher level. The influence of knowledge as a factor that influences the decision of paying zakat is in line with Mirawati's findings, Malik, and Ibrahim (2018). A muzakki is willing to spend part of his income to pay zakat, definitely based on knowledge of the substance of zakat. Paying zakat is not only distributing income, but also a meaning of a servant's obedience to Allah SWT. This is one principle difference that is often disputed between zakat and taxes. Zakat cannot be avoided because without being paid, zakat will come out of the compulsory zakat in the way that Allah desires, however, people can deny taxes in various ways. This method will be safe as long as "not caught".

Trust is also often raised as a factor influencing muzakki's decision to pay zakat. Maulidina and Solekah (2020) found that, the more someone believes in BAZNAS, the more muzakki's interest in paying zakat will increase. Mirawati, et al (2018) found that the nature of trust was insignificant, this is because the research was only devoted to the payment of professional zakat for civil servants (PNS) who generally paid zakat due to appeals from local agencies. The government has enacted regulations that began to be enacted and took effect on August 23, 2010 concerning zakat determination which can reduce gross income tax, provided that the tax is submitted to zakat institutions that have been established and legalized by the government. Furthermore, the Republic of Indonesia Law No. 23 of 2011 on zakat management was issued (Mirawati, Tanjung, and Arif (2019). Payment of zakat through such a mechanism is proven not/has not been accepted by everyone. This regulation is considered less strict because there is no criminal sanction or civil law that is given when muzakki does not pay zakat, the sanctions in question are only sanctions from Allah SWT as stated in the Qur'an. However, this institutional regulation of zakat payments has been proven to reduce consumption (Ridho and Herianingrum, 2019). The initial consumption behavior which only for buying favorite stuffs changes due to the allocation of zakat.

Institutions also have a significant influence on the decision to pay zakat. According to Ridho (2014), one of the urgencies of zakat in shaping welfare is the institutionalization of zakat as a guarantee that the collection, management, and distribution of zakat can be carried out optimally. In the view of muzakki (Yazid, 2017), the institutionalization of zakat provides guarantees about the reality, both formally and informally, that zakat is managed in a transparent, trustworthy, and professional manner. This method will increase muzakki's belief that the decision taken is correct, thus encouraging him to take another action.

Personal selling also has a negative effect on the decision to pay zakat. The interpretation of these findings can be linked to the institutional image (Yazid, 2017). Intensive socialization 
about the obligation to give zakat which is carried out institutionally is not always responded positively by all groups, even though it is carried out in Islamic institutions. So that, the more it is done intensively, it will create a feeling of antipathy from those who are actually obliged to zakat.

External motivation variable also has a significant effect on the decision to pay zakat. External motivation has a broad meaning. Anything that comes from outside oneself can mean external motivation. In this study, the purpose of external motivation is related to additional income outside of the basic salary, which means a fairly large income. Income arises from work which also has a significant effect. Nevertheless, Mirawati et al (2019) and Huda \& Ghofur (2012) prove that income has no significant effect, Maulana (2020) proves that zakat and income have an inelastic relationship. This research even shows the negative effect of income on the decision to pay zakat, additional income actually decreases the decision to pay zakat.

Mannan (1997) states that the higher a person's prosperity, the stronger the influence of psychological factors leads him to determine consumption, this is evidence of his failure to balance the fulfillment of his spiritual and physical needs. This is consistent with the opinion of Kotler \& Keller (2016) that among individual internal factors, psychological factors have a stronger influence than other internal factors besides cultural, social, and personal.

Promotion, persuasion, WOM, and personal selling, as factors that do not have a significant influence are one-way communication factors carried out by zakat management institutions. Zakat is not communicated like other products or services that are much more commercial. The encouragement to communicate personally from zakat management institutions was not done. According to Darma (2017), promotion does not even enter into the formation of people's perceptions and preferences to pay zakat. Although zakat is a very popular distribution system, its realization does not bring any popularity and personal gain. Therefore, only those who are truly fearful of Allah SWT are able to make it happen without frenetic documentation.

\section{Conclusions}

Zakat is an economic potential that has a potential comprehensive impact. Although zakat is an Islamic teaching that requires internal concrete evidence, it can be maximized by giving externally. This research proves that knowledge, trust, institution, internal motivation, and work are factors that have a significant influence on people's willingness to pay zakat. While promotion, persuasion, motivation between income, WOM, distribution and personal selling are factors that have no significant effect on people's willingness to pay zakat. The development of research results still needs to be done considering the ability of these factors to explain only $37 \%$.

\section{Acknowledgments}

For the publication of the results of this research, we would like to thank Fitrya, who has provided the opportunity to present ideas in scientific publication media. We also need to thank the reviewers who are willing to read, direct, and suggest some things that make this article becomes more meaningful. Last but not least, thanks to Abdul Basyith and Choiriyah who are always willing to be involved in small discussions in order to maximize academic value in life of an educator.

\section{References}


Andini, Ayu. 2020. Zakat Acceptance, Big Potential for Minimal Realization.https://lokadata.id/artikel/penerakuan-zakat-besar-p potential-minim-realisasi (accessed January 18, 2020)

Darma, Satria. Siregar, Saparuddin. Roka, Mustafa Kamal. 2017. Analysis of Muzakki's Perception of Preference and Decision to Choose Aal Zakat Institution. J-EBIS 2 (1): 1-22

Engel, James F, Miniar, Paul W, Blackwell, Roger D. 2012. Consumer Behavior. Canada: Nelson Education.

Kotler, Philip \& Keller, Kevin Lane. 2016. Marketing Management. England: Pearson Education Limited

Mannan, MA 1997. Theory and Practice of Islamic Economics. Yogyakarta; PT Dana Bhakti Prima Yasa

Maulana, Rizky. 2020. Individual Behavior in Zakat; The Effect of Income and Its Elasticity. Equilibrium: Journal of Shari'ah Economics 8 (1): 1 - 24

Maulidina, Ivada Hedi \& Solekah, Nihayatu Aslamatis. 2020. Antecedents of Zakat Paying Behavior at the National Zakat Board at the Lumajang Equilibrium: Journal of Syari'ah Economics 8 (2): 235 - 254

Mirawati, Dede. Malik, Zaini Abdul. Ibrahim, Mohamad Andri. 2018. Factors that affect the Interest in Paying Professional Zakat for the Employees of the Tanjungpandan Hospital Belitung. Proceedings of Shari'ah Economic Law 4 (2) 574 - 581

Mirawati, Nenden. Tanjung, Hendri. Arif, Suyud. 2019. Analysis of Factors Affecting Muzakki's Interest in Tithing at City Baznas. Research Dynamics 19 (1): 125 - 145.

National Zakat Statistics. 2018. National Zakat Agency.https://pid.baznas.go.id/wpcontent/uploads/2020/02/Statistik-Zakat-Nasional-2018.pdf (accessed January 18, 2020)

Ridho, Aris Kurniawan and Herianingrum, Sri. 2019. The Impact of Zakat Payment on the Consumption Behavior of Civil Servants in the Surabaya City Department of Sgama. Journal of Shari'ah Economics, Theory and Applied 6 (6): 1228 - 1241.

Ridlo, Ali. 2014. Zakat in Islamic Economic Perspective. Al 'Adl Journal 7 (1): 119-136

Rosana, Dolly. 2020. Realization of Zakat Collection at BAZNAS Palembang Misses.https://www.antaranews.com/berita/988202/realisasi-pengumpul-zakat-baznaspalembang-meleset (Accessed January 19, 2020)

Yazid, Azy Athoillah. 2017. Factors Affecting Muzakki's Interest in Paying Zakat at Nurul Hayat, Jember Branch. Economic: Journal of Islamic Economics and Law 8 (2): 173 - 199

\section{Copyrights}

Copyright for this article is retained by the author(s), with first publication rights granted to the journal.

This is an open-access article distributed under the terms and conditions of the Creative Commons Attribution license (http://creativecommons.org/licenses/by/4.0/) 